\title{
ERRATUM
}

\section{Real-Time Quantitative PCR Detection of Four Human Bocaviruses}

Kalle Kantola, Mohammadreza Sadeghi, Jenni Antikainen, Juha Kirveskari, Eric Delwart, Klaus Hedman, and Maria Söderlund-Venermo

Department of Virology, Haartman Institute, University of Helsinki, and Helsinki University Central Hospital Laboratory Division, Helsinki, Finland, and Blood Systems Research Institute and Department of Laboratory Medicine, University of California, San Francisco, San Francisco, California

Volume 48, no. 11, p. 4044-4050, 2010. Page, 4045, column 2, line 11: "0.3 $\mu$ M probe" should read "0.15 $\mu$ M probe." 